INTERNATIONAL JOURNAL OF RESEARCH IN SOCIAL SCIENCES \& HUMANITIES

An International Open-Access Peer Reviewed Referred Journal

\title{
EXAMPLES OF PROHIBITED BANKING
}

\section{Dr. Asmaa Abdul-Jabbar Odeh}

Department of Islamic Finance and Banking, College of Islamic Sciences, Baghdad University

DOI: http://doi.org/10.37648/ijrssh.v12i01.002

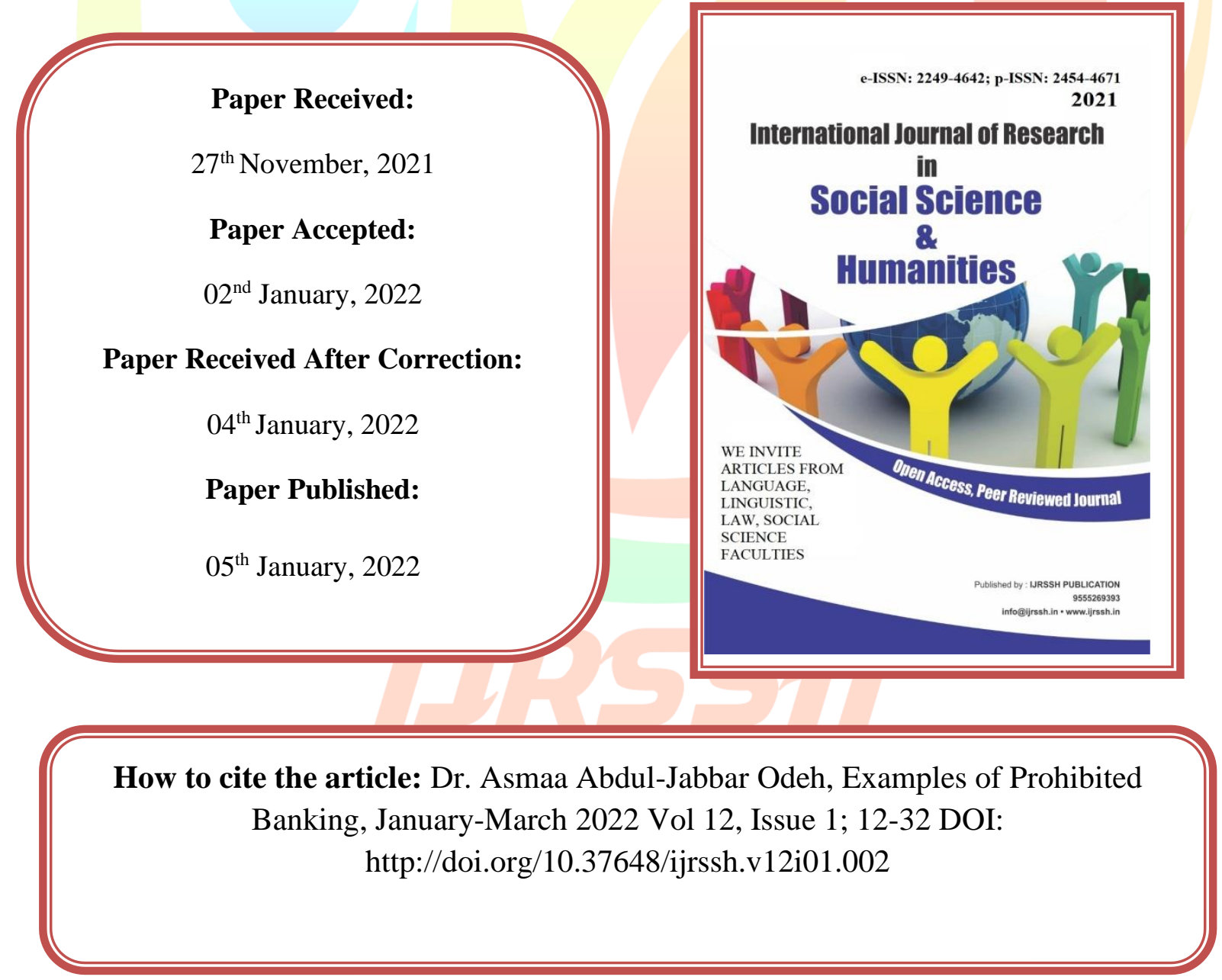




\begin{abstract}
The banking business that you should not conduct in Islamic banks is in the matter of exchange, including the exchange on the basis of the deferred price and the discount of commercial papers. Also, if the exchange contract does not meet its legal conditions, then he signs a contract in one of the two types of usury Al-Fadl or Al-Nasee'ah usury, or both as it will be explained, if he wishes. God, and perhaps the wisdom behind the prohibition of usury of an-Naseeh arising from the sale of cash for money other than its kind, when the forward factor in the price is taken into account, was not noticed by many to the extent that some were overwhelmed by surprise and astonishment when they learned that the Shari'a forbade this form of transaction. The paper is begins with the definition of parallel exchange and its legal adaptation and a statement of the pillars and conditions of the exchange contract and exchange work in contemporary Islamic banks. It was concluded that it is not permissible to deal with the exchange at the forward rate.
\end{abstract}

Keywords: Banned, Exchange, parallel. 


\section{Volume: 12, Issue: 1, January-March 2022}

\section{INTRODUCTION}

Praise be to Allah, we praise, seek His help, seek His forgiveness, and seek refuge in Him from the evils of ourselves and from the evils of our actions. He who guides Allah, there is no misleading him, and he who misleads, there is no guide for him, and I bear witness that there is no Allah but Allah alone without partner, and that Muhammad is His servant and His Messenger (peace be upon him) until the Day of Judgment, and greetings very much.

Economic and commercial activities have developed and diversified in the current era more than ever before. Therefore, it must necessary to find Islamic solutions to many of the emerging issues related to them, whether they are directly or indirectly related to the old or not, in support of the Islamic economic movement, and the consolidation of its principles, goals and rulings in the light of what is between the Qur'an and Sunnah and the jurisprudence of jurists.

The banking business that you should not conduct in Islamic banks is in the exchange section, including the exchange on the basis of the deferred price and the discounting of commercial papers. If the exchange contract does not fulfill its legal conditions, then he signs the contract with one of the two types of usury Al-Fadl or usury Al-Nasee'ah, or both, as will be explained, Allah willing. Perhaps the wisdom behind the prohibition of usury an-Naseeh arising from the sale of cash for money other than its kind, when the forward factor in the price is taken into account, was not noticed by many to the extent that some were overwhelmed by surprise and astonishment when they learned that the Shari'a forbade this form of transaction.

1- As mentioned above, there will be a need for people to understand and know the legitimate forms of other banking business so that the Muslim does not fall into the forbidden.

2- As a result of these reasons, the importance of this topic appears, as it is a modern topic, where it discusses emerging issues that were not known before. Also because of the multiplicity of forms of exchange as a result of the means and methods available in this era that were not available in previous eras.

3- There is also the prevalence of dealing with exchange in all its modern forms, including the exchange on the basis of the present and deferred price, which is considered the lifeblood of many 
Muslims at the present time, especially among merchants, which makes the need to study and explain its ruling to people from a legal point of view.

The aims of this research to identify the position of Islamic Sharia on banking business in terms of spending on the basis of the present and on the basis of deferred, and why does it require its prohibition, and what is the legal position in it.

To analyses and solve this problem, the preparation of this research required us to adopt a specific approach, which is the following:

1- The scientific material was collected from its contents and all the information mentioned in the research was documented, by attributing it to the one from whom it was transmitted.

2- I attributed the Qur'anic verses to their Surahs with mentioning the verse number.

3- The hadiths mentioned in this paper have been extracted, as if the hadith is in two Sahihs or in one of them, it is sufficient to refer to it or to them, otherwise I have extracted it from the books of Sunan, Musnad and Athar.

This research will deal with an introduction, a topic, demands, and then a conclusion. It is divided as shown below:
This paper is includes an introduction, a topic, demands, and then a conclusion.

The first topic: the parallel exchange of the currency and the exchange on the basis of the deferred rate. This topic is divided into five demands, where the first requirement means defining the parallel exchange in language and idiomatically. As for the second requirement, it will deal with its legal adaptation. It also deals with the elements of the exchange contract, and the fourth requirement will deal with the conditions of the exchange contract, as well as the fifth requirement studies the exchange work in contemporary Islamic banks. We will also discuss the conclusion and the most important results obtained from the research.

THE FIRST TOPIC: PARALLEL CURRENCY EXCHANGE AND EXCHANGE BASED ON DEFERRED RATE

The parallel exchange of the currency and the exchange on the basis of the deferred rate is divided into two requirements:

The First Requirement: Defining Parallel Exchange, Linguistically and Idiomatically.

Firstly: To grammatical exchange language: to turn something away from its face or to replace it with something else: it 
is said: to exchange it is to exchange it completely if it is returned $\left({ }^{1}\right)$.

Secondly: Exchange idiomatically: The majority of scholars (Hanafi, Shafi'i and Hanbali) defined it as the sale of two currencies with one another $\left({ }^{2}\right)$, whether they were united in gender or differed $\left(^{3}\right)$.

The Hanbalis defined it as (sale / cash for cash) $\left({ }^{4}\right)$.

As for the Malikis, they restricted the meaning of exchange to the sale of two currencies only when the sex is different, and they said: Exchange is (the sale of gold for silver) $\left({ }^{5}\right)$, but if the two currencies are of the same sex, they call it

(1) Lisan Al-Arab, Muhammad bin Makram, Ibn Al-Manzour, (T: 711 AH), Edition 3, Dar Sader Beirut, $1414 \mathrm{AH}$, the neglected chapter: 9/189.

( ${ }^{2}$ Al-Mabsout, Shams Al-Din Abu Bakr Al-Sarkhi, investigation: Khalil Mohi Al-Din Al-Mays, 1st edition, Dar Al-Fikr, Beirut - Lebanon: 2/14

${ }^{3}$ )The Clear Sea, Explanation of the Treasure of Minutes and its Margin, the Grant of the Creator, Zain Al-Din Ibn Najim Al-Hanafi, Edition 1, Dar Al-Kutub Al-Arabiya (6/209), a footnote to the response of Al-Mukhtar to Al-Durr Al-Mukhtar, footnote, Muhammad Amin Ibn Abidin, Dar AlFikr, Beirut - Lebanon, 1412 AH - 1992 AD: 5/257. $\left({ }^{4}\right)$ Minutes of Oli Al-Noha to Explain the Ultimate Known as Sharh Muntaha Al-Iradat, Mansour bin Younis bin Idris Al-Bahouti Al-Hanbali (T.: 1051 AH), i 1, Alam Al-Kutub, 1414 AH - 1993 AD: 2/73, Persuasion, Abu Al-Nada Sharaf Al-Din AlHijjawi, Dar Al-Maarifa, Beirut, Lebanon :2/121. (5)Al-Desouki's footnote on the Great

Commentary, (T.: $1201 \mathrm{AH}$ ), and in the margin are the reports of Alish, (T.: 1299 AH), Muhammad bin Ahmed bin Arafa Al-Desouki, Edition 1, Dar Al-Kutub Al-Ilmiyya, Lebanon - Beirut, 1417 AH 1997 AD: 3/35. by equivocation in the sale by weight, or by the exchange in the sale by count $\left({ }^{6}\right)$.

But the chosen opinion is the definition of the public, where the concept of exchange is broader and more comprehensive for selling prices to each other when gender is united or different.

\section{Thirdly: Exchange in modern}

economics: It is the process of exchanging money for one another $\left(^{7}\right)$.

It was defined as (the buying and selling of foreign currencies) $\left({ }^{8}\right)$, and it was defined as (the conversion of one currency into another) $\left({ }^{9}\right)$.

It is noted here that the economists' definition of exchange is more specific than the public's definition, as it is for economists that it is limited to the exchange of currencies with each other only and does not include the exchange of a currency with its parts, as it is not considered an exchange and also does not include the exchange of currency for gold

${ }^{6}$ ) The previous source, in the language of the traveler, to the closest path to the small explanation, by the pole Sidi Ahmed Al-Dardir, Abu Al-Abbas Ahmed bin Muhammad Balsawi AlMaliki (T.: 1241 AH), Dr. i, d. C, Dar Al-Maaref: 3/63, Hashiyah Al-Desouki, Al-Desouki: 3/35. (7)The basic rules of international economics, $d$. Muhammad Ali Reda Al Jassim, (Al-Tadamon Press, Baghdad, 1967 AD): 325.

${ }^{8}$ )Encyclopedia of Economic and Statistical Terms, Abdel Aziz Fahmy Haikal, Dar Al-Nahda Al-

Arabiya, Beirut - Lebanon :306.

$\left({ }^{9}\right)$ The Economic Encyclopedia, Adel Hassan Abdul-Mahdi Al-Hamondi, 1st Edition, Ibn Khaldoun House, Beirut - Lebanon, 1980: 303. 
or silver as it is not considered money but rather commodities, and hence the concept of exchange in Islamic law is broader and more comprehensive. The exchange of one currency for another takes place on the basis of a price relationship between them, which is called the exchange rate, and it means: the price or rate on the basis of which a particular currency is exchanged for another $\left({ }^{10}\right)$.

\section{The Second Requirement: His Legal}

\section{$\underline{\text { Adaptation }}$}

Exchange is a type of permissible sale, but it is a sale with specific conditions that are not found in other types of sales and distinguish it from other contracts. Its ruling is that it is a legitimate sale, its legitimacy is proven by the Book, the Sunnah, consensus and reasonableness.

\section{First: The Holy Qur'an}

The word sale is mentioned fourteen $\left({ }^{11}\right)$ times in the Qur'an, and this is evidence of the legality of selling, including:

Almighty saying: [Whereas Allâh has permitted trading and forbidden Ribâ (usury)]( $\left.{ }^{12}\right)$, Almighty saying:[Eat not up your property among yourselves unjustly

$\left({ }^{10}\right)$ Encyclopedia of economic and statistical terms, structure: 306.

${ }^{(11) I n t r o d u c t i o n ~ t o ~ I s l a m i c ~ E c o n o m i c s, ~ A l i ~ M a s h a e l, ~}$ 1st floor, Ras Al Khaimah - United Arab Emirates, 1714-1996 AD: 20

${ }^{(12)}$ Surah Al-Baqarah from verse: 275. except it be a trade amongst you, by mutual consent] $\left({ }^{13}\right)$.

The significance of the generality of these two verses is the permissibility of absolute sale, and since exchange is a type of sale, it is covered by the ruling of legality and permissibility.

\section{Second: The purified year}

There are many hadiths that indicate the legitimacy of the exchange, including:

1. What the two sheikhs narrated: The Messenger of Allah (peace and blessings of Allah be upon him) said: "Allah for gold is interest except ha and ha' $\left({ }^{14}\right)$ and righteousness with righteousness is interest without ha and ha, and dates with dates is interest without ha and ha, and barley with barley is interest without ha and ha." $\left({ }^{15}\right)$, that is, hand in hand.

${ }^{(13)}$ Surah An-Nisa from verse 29.

$\left.{ }^{14}\right)$ His saying $\mathrm{Ha}$ ' and $\mathrm{Ha}$ ' is a profession of take and give or take and give, and in both of them are the two languages of tide and qasr, and the tide is more eloquent and famous, and its origin is here, so I changed the mother from the kaf. See: Al-Musnad Al-Sahih Al-Mukhtasar Al-Adl Al-Adl Al-Adl to the Messenger of God, may God bless him and grant him peace, Muslim bin Al-Hajjaj Abu AlHasan Al-Qushayri Al-Naysaburi, (T.: 261 AH), Investigator: Muhammad Fouad Abdul-Baqi, House of Revival of Arab Heritage - Beirut: 3/1209.

${ }^{15}$ )Al-Jami Al-Sahih Al-Mukhtasar, Muhammad bin Ismail Abu Abdullah Al-Bukhari Al-Jaafi, investigation and commentary: Dr. Mustafa Dib Al-Bagha, 3rd Edition, Dar Ibn Katheer, AlYamamah - Beirut, 1407-1987, Chapter of What is Mentioned in the Sale of Food and Hakrah, Hadith No. 2027: 2/750, Sahih Muslim, Chapter on 
2. What was narrated by the two sheikhs:

The Messenger of Allah (May Allah blesses him and grants him peace) forbade: "Silver for silver, and gold for gold, except that the same is equal. I heard" $\left({ }^{16}\right)$.

3. What the two sheikhs narrated: "The Messenger of Allah (May Allah bless him and grant him peace) forbade selling paper for gold as debt" $\left({ }^{17}\right)$, that is, deferred without payment upon contracting.

The evidence from the previous hadiths is that when he (peace and blessings of Allah be upon him) forbade the sale of cash except with pictures and conditions that the Prophet, peace and blessings be upon him, excluded, this indicates the legality of the exchange if its conditions are met.

\section{Third: Unanimity}

The fuqaha' have unanimously agreed on the legality of the exchange contract with its legal conditions. It was reported on the authority of Ibn Mubarak that he said (there is no difference in the exchange)

Exchange and Selling Gold in Paper for Cash, Hadith No. 1586: 3/1209.

$\left.{ }^{16}\right)$ Sahih al-Bukhari, chapter on selling gold for paper hand in hand, Hadith number 2071: 2/762, Sahih Muslim, chapter on the prohibition of selling gold for paper as a debt, Hadith number 1590: 2/1213

${ }^{(17)}$ Sahih al-Bukhari, chapter on selling paper for gold on credit, hadith number 2070: 2/762, Sahih Muslim, chapter on the prohibition of selling paper for gold as a debt, hadith number 1589: 2/1212.
(18). Imam Al-Nawawi said: "The scholars are unanimously agreed that it is forbidden to sell gold for gold or silver for silver at a deferred payment, and likewise everything they share in the cause of usury" $\left({ }^{19}\right)$.

\section{Fourth: reasonable}

The principle in contracts is permissibility and validity unless he sees evidence of its prohibition or invalidation by text or analogy. The obligation to fulfill contracts is according to the consent of the two contracting parties, unless the contract includes a condition contrary to the law of Allah Almighty, such as damage, exploitation, and forbidden interest. Therefore, the principle in the exchange contract is the solution until proven Evidence for its sanctity, as nothing came from the wise legislator that required its sanctity, but rather its permissibility and legislation as it came in the authentic Sunnah that we mentioned earlier. And people's need to exchange currencies to facilitate their transactions in their working lives. There may be a person who has the currency of his country (dinars, dirhams, or other things) and he is in a country that they only sell in dollars, euros or lira, and

${ }^{18}$ )The Great Mosque - Sunan Al-Tirmidhi, Muhammad bin Isa bin Surah bin Musa bin AlDahhak, Al-Tirmidhi, Abu Issa (died: 279 AH)

$\left({ }^{19}\right)$ Investigator: Bashar Awad Maarouf, Dar alGharb al-Islami - Beirut, 1998 AD: 2/534. 
he needs to exchange it, because preventing him is restricting people $\left({ }^{20}\right)$.

\section{The Third Requirement: The Elements of The Exchange Contract}

It appeared from the previous definitions of the jurists that the exchange is a sale, it is one of the legitimate sales contracts, and since the exchange contract is a contract of sale, it must meet the elements and conditions that must be met in all other sales contracts.

The pillars of the contract of sale are well known to the jurists, which is the contract formula (the acceptance, the offer and the mutual consent of the two parties to what they contracted), then the two contracting parties themselves and their conditions (adulthood, reason and choice). The contract is not valid and necessitates the sequence of its provisions and effects unless it is issued by its people in addition to the place on which the agreement was signed to oblige each of the contracting parties to do what is in his possession for its owner $\left({ }^{21}\right)$.

These pillars must be detailed because they have been mentioned in detail in the books

${ }^{(20) A l-M i n h a j ~ E x p l a n a t i o n ~ o f ~ S a h i h ~ M u s l i m ~ B i n ~}$ Al-Hajjaj, Abu Zakaria Mohi Al-Din Yahya Bin Sharaf Al-Nawawi, (T.: 676 AH), i 2, House of Revival of Arab Heritage - Beirut, 1392: 11/10.

${ }^{(21)}$ Provisions of money and currency exchange in Islamic jurisprudence and its contemporary applications, d. Abbas Ahmed Muhammad Al-Baz, 1st floor, Dar Al-Nafais, 1419 AH - 1999 AD: 36. of jurists regarding the essential elements of a contract of sale, which are required for a contract of exchange, whether or not. The exchange contract differs from other types of sale, as it is concerned with selling prices to one another, which prompted the legislator to its jurisdiction with conditions exceeding the well-known terms of sale. Also, to explain these conditions to demonstrate their importance and the wisdom of the legislator from their requirement and the exclusion of the exchange contract with them.

\section{The Fourth Requirement: The Terms of The Exchange Contract}

The wise legislator laid down conditions for the exchange contract between the contracting parties, which were not stipulated in other contracts, and that is why it is important and close to usury. The following is an explanation of these conditions:

\section{The first condition: Symmetry in destiny} when the sex is united

The general principle in the matter of exchange: If the races are united, equality is required. It is stipulated in the exchange contract that there is similarity in the amount without an increase or decrease in the union of sex, and the content of the rule is the prohibition of differentiation in the same sex from usury funds if some of 
it is sold for another, such as selling a dirham for two dirhams or a dinar for two dinars $\left({ }^{22}\right)$. The excess in the sale of cash of the same kind is called usury Al-fadl, and the same is forbidden for the credit, such as delaying the delivery of one of the two exchanges to the contract session, because of the usury of women. The consideration of the condition of symmetry is waived when the sex is different, so differentiation is not prohibited, but it is required to dissolve and interact in the meeting of the contract. There have been many hadiths indicating the prohibition and prohibition of differentiation in the same sex.

a- From Abu Hurayrah (ra) said: The Messenger of Allah (peace be upon him): ((gold plated weight by weight, for example such, silver for silver weight by weight, for example such, it is increased or Astzad is riba)) $\left({ }^{23}\right)$.

b- On the authority of Abu Hurairah (ra) who said: The Messenger of Allah (peace be upon him) said: ((A dinar is for a dinar, there is no preference between them, and a

(22) Previous source: 36.

(23) Indian Fatwas, Committee of Scholars headed by Nizam al-Din al-Balkhi, 2nd Edition, Dar alFikr, 1310 AH: 2/217. dirham is for a dirham, there is no preference between them)) $\left({ }^{24}\right)$.

c- Abu Sa'eed that, the Messenger of Allah (peace be upon him) said: ((then, do not gold in gold, but for example, such and healed each other and Etbiawa paper to paper, but, for example, such and healed each other and Etbiawa of them absent Bnajz )) $\left({ }^{25}\right)$.

The evidence from these hadiths and many others is the prohibition of differentiation when selling sex for the same from the same group, as well as the prohibition of usury Al-Fadl or Al-Nasee'ah usury.

\section{THE SECOND CONDITION: IT IS OBLIGATORY TO COLLECT THE TWO EXCHANGES IN THE CONTRACT SESSION}

The jurists unanimously agreed that the exchange is a condition of the exchange due by the contract as a right of Allah Almighty, and it is not permissible to forfeit it by the consent of the contracting parties $\left({ }^{26}\right)$. And the evidence for the necessity of arresting them is the hadith of Abu Saeed Al-Khudri, who said: My eyes

${ }^{(24) S a h i h ~ M u s l i m, ~ A l-M u s a q a h ~ B o o k, ~ C h a p t e r ~ o n ~}$ Exchange and Selling Gold in Paper for Cash, Hadith No. 1588/84:3/1212

${ }^{25}$ )Previous source, Al-Musaqah Book, Chapter on Exchange and Selling Gold in Paper for Cash, Hadith No. 1588/85: 3/1212

${ }^{(26)}$ The previous source, Al-Musaqah Book, the chapter on usury, Hadith No. 1584/78: 3 /1209 
saw and my ears heard the Messenger of Allah (May Allah bless him and grant him peace) saying: "Do not sell gold for gold, and do not sell paper for paper, and do not sell it for anything except for something like that." $\left({ }^{27}\right) \mathrm{He}$ is absent from him except hand in hand." (28) Al-Nawawi said "His saying - peace be upon him - hand in hand: is an argument for all scholars on the necessity of intercourse and that the sex differ" $\left({ }^{29}\right)$.

\section{THE THIRD CONDITION: THE} EXCHANGE CONTRACT IS FREE OF THE OPTION OF THE CONDITION FOR THE TWO EXCHANGERS OR ONE OF THEM

The majority of scholars are of the view that the option of the condition is not proven in the exchange contract $\left.{ }^{(30}\right)$, because the exchange is not likely to be postponed, and the option necessitates and

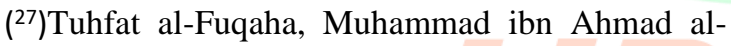
Samarqandi (T.: 540 AH), Edition 2, Dar al-Kutub al-Ilmiyya, Beirut - Lebanon, 1414 AH - 1994 AD: $3 / 35$.

${ }^{(28)}$ The consensus, Muhammad bin Ibrahim bin AlMundhir Al-Nisaburi (died: 318 AH), investigation: Dr. Fouad Abdel Moneim Ahmed, Dar Al-Da`wah, Alexandria, 1402: 92

${ }^{(29) S a h i h ~ M u s l i m, ~ A l-M u s a q a h ~ B o o k, ~ C h a p t e r ~ o n ~}$ usury, Hadith No. 1584/77: 3 / 1208

(30)Al-Minhaj Explanation of Sahih Muslim bin AlHajjaj, Abu Zakaria Al-Nawawi (T.: 676 AH), 2nd Edition, House of Revival of Arab Heritage Beirut 11/14 1392. prevents ownership and the obligation of the contract $\left({ }^{31}\right)$.

\section{FOURTH CONDITION: THE} EXCHANGE CONTRACT MUST BE FREE OF A TERM.

If the term or condition of the two contracting parties is found, the exchange is spoiled, because the receipt of the two exchanges is due before the separation and the term prevents the payment due in the contract, so the contract is invalidated for the emergency term on it. Which is proven in hadiths that forbid respite because it leads to forbidden usury.

\section{The Fifth Requirement: Exchange Work in Contemporary Islamic Banks}

Banks provide the service of exchange and monetary exchange between different currencies, which plays a major role to provide the need of foreign currency dealers with the bank in order to carry out cash transfers for import purposes, and all their needs of currencies, and Islamic banks apply the provisions of exchange on these transactions such as hand-to-hand when contracting On exchanging the national currency with foreign currencies, and we will study in this requirement the

${ }^{(31)}$ It is that the two contracting parties, or one of them, stipulate in the contract an option for a known period, so that the owner of the option has the right to sign or cancel the contract during this period. I, Cairo Library, 1388 A.H. - 1968 A.D.: $4 / 73$. 
different forms practiced by contemporary banks with regard to how to exchange currencies, as the practical application in the banking field takes place within two distinct scopes. The first: in which exchange and currency exchange takes place on the basis of the current rate, and the second: in which the exchange and exchange of currency takes place on the basis of the forward rate $\left({ }^{32}\right)$. We will study these two images as follows.

\section{Scenario One: The exchange is based on the current price}

It means the exchange operations in which the exchange takes place hand in hand between the two parties (the bank and the customer), or what takes their place in the contract council based on the prevailing exchange rate in the market on the day of the transaction, in accordance with the first criterion of the Sharia standards for Islamic financial institutions $\left({ }^{33}\right)$.

Banks practice this process, and exchange foreign currencies on the basis of the current price, as the banking process takes place here by showing each of the exchangers what they want to exchange for

${ }^{(32}$ Provisions of money and currency exchange in Islamic jurisprudence and its contemporary applications, d. Abbas Ahmed Mohamed El-Baz: 73

${ }^{(33)}$ The Comprehensive Introduction to Islamic Banking Transactions and Operations, Mahmoud Abdel-Karim Irsheed, I 1, Dar Al-Nafaes, Jordan, 2015: 59. the other currency. This exchange takes place at the exchange rate on the day of the exchange, provided that it fulfills the conditions of legal exchange from the immediate hand-to-hand payment. This is the usual exchange process that takes place between individuals and exchange houses. Except for the exchange process that takes place with banks (banks), not all of it takes place in this way. Rather, the banking process in banks takes place on multiple ways according to the customer's needs in two ways $\left({ }^{34}\right)$ :

a- The exchange is based on the current price if it is cash from the fund

In this method, the banking process obtains cash on the fund, either by exchanging a foreign currency with a local currency or by exchanging a local currency with a local currency of its kind on the basis of the current price. It is in the following form: If the customer hands the cashier the equivalent of the currency he wants to pay in, he is recorded in his account according to the exchange process the equivalent of the foreign currency, so he exchanges between two different currencies (a currency from the minting

${ }^{(34) P r o v i s i o n s ~ o f ~ M o n e y ~ a n d ~ C u r r e n c y ~ E x c h a n g e ~ i n ~}$ Islamic Jurisprudence and its Contemporary Applications, Abbas Ahmed Muhammad Al-Baz: 205, Shari'a Standards, Accounting and Auditing Organization for Islamic Financial Institutions, (1435 A.H. - 2014 A.D.), Standard No. (1) Currency Trading: 4 
and printing of a country different from the other) in this case it applies to him Ruling on spending when the difference of sex dinars exchange dirhams $\left({ }^{35}\right)$.

The Shariah ruling in such a situation requires that it is permissible because there is nothing that contradicts it, and that the legal conditions for the validity of this exchange is fulfillment and exchange, it sells the currency. But if the exchange is made in cash from the fund between a local currency and a local currency of its kind, then to the previous conditions is added the condition of similarity in the amount, then it is not permissible to differentiate in this case $\left({ }^{36}\right)$.

b- The exchange on the basis of the current price if it is a restriction on the account

If the customer has an account in a bank and he has a foreign currency and he wants to deposit it in his account in the national currency, then in this case he submits a request to the bank to exchange the foreign currency in his hand into a national currency and register it in his account. In

${ }^{(35)}$ Provisions of Money and Currency Exchange in Islamic Jurisprudence and its Contemporary Applications, Abbas Ahmed Muhammad Al-Baz: 207, The Comprehensive Introduction to Islamic Banking Transactions and Operations, Mahmoud Abdel-Karim Irsheed: 59.

${ }^{(36)}$ The previous source, Sharia Standards, Accounting and Auditing Organization for Islamic Financial Institutions: 4, Provisions of Exchange in Islamic Jurisprudence, Adel Muhammad Amin AlTayeb, Master's Thesis, (1416-1996AD): 264. this case, the bank calculates the value of the amount paid by the customer in the currency and depositing it in his account without the hand-to-hand exchange taking place in the contract council, and the process in this way is permissible according to Shariah law. If we know that hand-to-hand arrest does not mean arrest by the victim, but if it is placed in his pocket or a bag, then this is considered seizure if it is in the council, and the same is true if the amount is recorded in his account before separation.

But if the customer has the national currency and he wants to obtain foreign currency, then he submits a request to the bank to exchange the amount and deduct its value from his account, as the bank deals as an agent with payment or discount when buying and adding when selling in the current account, then this is permissible provided that he receives foreign money From the bank before the parting, and that the exchange is done at the exchange rate on the basis of the present, because this form is one of the forms of exchange in the custody, because the bank deposit is like a loan in the bank's custody $\left({ }^{37}\right)$.

$\left.{ }^{(37}\right)$ The provisions of exchange in Islamic jurisprudence, Adel Muhammad Amin Al-Tayeb: 264, The Comprehensive Introduction to the Transactions and Operations of Islamic Banks, Mahmoud Abdel-Karim Irsheed: 60. 
We note from the foregoing that the entry in the account is considered an exchange by the client, because the account belongs to the client, so it is considered as a legal container or portfolio.

\section{The second scenario: The exchange on} the basis of the forward rate

It is from the work of the Central Bank to the banks that it shows on a daily basis the prevailing price in the market for buying and selling currencies, which is called the exchange at the present rate. The two methods have already been mentioned that it is permissible for an Islamic bank to practice this activity of exchange. As for the exchange on the basis of the forward rate, it is a process that takes place based on a price that is determined immediately in return for delaying the delivery of the two exchanges, and this process is one of the contemporary transactions in the field of banking $\left({ }^{38}\right)$, where we will deal In this picture of its meaning, uses, need, purpose and areas of use, then we show the legal position on the forward rate exchange process.

\section{First: Its meaning and the need for it}

The basis of the exchange process at the forward rate is based on the agreement to conclude the exchange contract and to carry out the banking process based on a

(38)Previous source: 266. specific exchange rate on the day of the conclusion of the contract, provided that the actual delivery and receipt of the exchanged currencies at a later time to the date of the contract, in a period ranging from one month to three months, and six to six months, and nine months, a year. There is a time period between contracting and delivery, where interest plays a major role in determining the forward exchange rate. "The principle of equal difference in the forward rate from the price in cash with the interest rate difference on the two currencies subject of the operation is a basic principle of the forward currency market principles" $\left({ }^{39}\right)$.

\section{Second: The purpose of the exchange at} the forward rate and the areas of its use

The exchange dealers resort to it on the basis of the forward rate in order to stabilize the exchange rate at a certain limit and to ensure that there is no change in the exchange rate in the future. In this way, the dealers secure themselves from the risks of currency fluctuations in the forward exchange market, as well as the emergence of the importance of the forward exchange for dealers with import business and export, especially that the

${ }^{(39}$ Provisions of Money and Currency Exchange in Islamic Jurisprudence and its Contemporary Applications, Abbas Ahmed Muhammad Al-Baz: 215, The Comprehensive Introduction to Islamic Banking Transactions and Operations, Mahmoud Abdel-Karim Irsheed: 61. 
payments are future, so it is resorted to ensure the stability of a future exchange rate. It is a precautionary deal whose purpose is to stabilize the exchange rate at a certain limit, and the exchange will take place in the future.

\section{Third: The legal position}

The immediate exchange is a condition for the validity of the exchange, and the scholars are unanimously agreed that if the exchangers parted before the exchange, the exchange was invalid $\left({ }^{40}\right)$. Since the exchange on the basis of the forward rate is based on the establishment of the exchange contract free of receipt, then it is an exchange devoid of receipt, and the capture is a basic condition for the validity of the exchange contract, and it is a condition agreed upon. From this condition of receipt on the one hand, and on the other hand, the exporter, importer or investor who deals in exchange on the basis of the forward price when he sells what he will receive from his work in the future, he sells the cash before receiving it.

Evidence for that:

- Hakim bin Hizam hadeeth with Ahmad, he said: I said, O Messenger of Allah: "I buy in

$\left.{ }^{40}\right)$ Provisions of money and currency exchange in Islamic jurisprudence and its contemporary applications, Abbas Ahmed Muhammad Al-Baz: 216. merchandise, so what is permissible for me from it and what is forbidden for me? He said: If you buy something, do not sell it until you take possession of it" $\left({ }^{41}\right)$.

- The hadith of Ibn Abbas that the Prophet (May Allah bless him and grant him peace) said: "Whoever buys food, he does not sell it until he has taken it." Ibn Abbas said: I count everything except for the same $\left({ }^{42}\right)$.

The two hadiths indicate that it is not permissible to sell any commodity purchased until after the seller has taken possession of it and received it. Therefore, the exchange on the basis of the forward rate is prohibited and it is not permissible for a Muslim to deal with it.

Where the first criterion was taken that the forward exchange is not permissible, it stipulated in Article 2/1/c: that the dealing in currencies should not take place in the forward market.

$2 / 2$ : It is forbidden to deal in the forward exchange market, whether it is done by

$\left.{ }^{41}\right)$ Consensus, Abu Bakr Muhammad bin Ibrahim bin Al-Mundhir, (T.: 319 AH), Investigator: Fouad Abdel Moneim Ahmed, Edition 1, Dar Al-Muslim (1425 AH / 2004 AD): 97.

${ }^{(42)}$ Musnad of Imam Ahmad bin Hanbal, Abu Abdullah Ahmad bin Muhammad bin Hanbal (T.: 241 AH) Investigator: Shuaib Al Arnaout - Adel Murshid, and others Supervised by: Dr. Abdullah bin Abdul Mohsen Al-Turki, 1st Edition, Message (1421 AH - 2001 AD) No. $15316: 2 / 32$. 
exchanging forward transfers or by concluding deferred contracts in which the receipt of the two exchanges, or both, is not achieved.

2/3: Forward exchange is also prohibited, even if it is to prevent a decrease in the profit of a transaction that takes place in a currency whose value is expected to decrease $\left({ }^{43}\right)$.

The legitimate way out: Because foreign trade is based on the exchange of currencies at their exchange rate. Delivery takes place after a period of setting a selling price, and given the adoption of the dollar as a basis for determining the exchange rate of most currencies, and because the fluctuation in currency rates continues. The legitimate way out for this type of transaction is to purchase by way of Murabaha, whereby the importer authorizes the bank to purchase the commodity, provided that the bank sells the commodity to the importer in the local currency at the market exchange rate on the day of delivery. Other than this, the forward exchange is not permissible, for the texts and rules of Sharia forbid it, as it is similar to gambling and speculating on currency rates, both of which are prohibited by Sharia because of the harm

${ }^{(43)}$ Sharia standards, Accounting and Auditing Organization for Islamic Financial Institutions, Supplement No. (1): 5. that it involves, and harm is prohibited in Islam $\left({ }^{44}\right)$.

\section{CONCLUSION}

Perhaps the most prominent results demonstrated by this research.

1- Dealing with exchange is tainted by the risk of falling into usury if the conditions considered for its validity are not observed.

2- The exchange operations on the basis of the present price are that the condition of arrest, delivery and hand-to-hand receipt is fulfilled, or what takes their place in the contract council, based on the prevailing exchange rate on the day of the sale. It is agreed upon in order to prevent the rise in the exchange rate, in this case it is not permissible.

$\left({ }^{44}\right)$ The provisions of money and currency exchange in Islamic jurisprudence and its contemporary applications, Abbas Ahmed Muhammad Al-Baz: 221. 


\section{Volume: 12, Issue: 1, January-March 2022}

\section{MARGINS}

1- Lisan Al-Arab, Muhammad bin Makram, Ibn Al-Manzour, (T: 711 AH), Edition 3, Dar Sader Beirut, 1414 AH, the neglected chapter: 9/189.

2- Al-Mabsout, Shams Al-Din Abu Bakr Al-Sarkhi, investigation: Khalil Mohi Al-Din Al-Mays, 1st edition, Dar Al-Fikr, Beirut - Lebanon: 2/14

3- The Clear Sea, Explanation of the Treasure of Minutes and its Margin, the Grant of the Creator, Zain Al-Din Ibn Najim Al-Hanafi, Edition 1, Dar Al-Kutub Al-Arabiya (6/209), a footnote to the response of Al-Mukhtar to Al-Durr Al-Mukhtar, footnote, Muhammad Amin Ibn Abidin, Dar Al-Fikr, Beirut - Lebanon, 1412 AH - 1992 AD: $5 / 257$.

4- Minutes of Oli Al-Noha to Explain the Ultimate Known as Sharh Muntaha Al-Iradat, Mansour bin Younis bin Idris Al-Bahouti Al-Hanbali (T.: 1051 AH), i 1, Alam AlKutub, 1414 AH - 1993 AD: 2/73, Persuasion, Abu Al-Nada Sharaf Al-Din AlHijjawi, Dar Al-Maarifa, Beirut, Lebanon :2/121.

5- Al-Desouki's footnote on the Great Commentary, (T.: $1201 \mathrm{AH}$ ), and in the margin are the reports of Alish, (T.: 1299 AH), Muhammad bin Ahmed bin Arafa AlDesouki, Edition 1, Dar Al-Kutub Al-Ilmiyya, Lebanon - Beirut, 1417 AH 1997 AD: $3 / 35$.

6- The previous source, in the language of the traveler, to the closest path to the small explanation, by the pole Sidi Ahmed Al-Dardir, Abu Al-Abbas Ahmed bin Muhammad Balsawi Al-Maliki (T.: 1241 AH), Dr. i, d. C, Dar Al-Maaref: 3/63, Hashiyah Al-Desouki, Al-Desouki: 3/35.

7- The basic rules of international economics, d. Muhammad Ali Reda Al Jassim, (AlTadamon Press, Baghdad, 1967 AD): 325.

8- Encyclopedia of Economic and Statistical Terms, Abdel Aziz Fahmy Haikal, Dar AlNahda Al-Arabiya, Beirut - Lebanon :306.

9- The Economic Encyclopedia, Adel Hassan Abdul-Mahdi Al-Hamondi, 1st Edition, Ibn Khaldoun House, Beirut - Lebanon, 1980: 303.

10- Encyclopedia of economic and statistical terms, structure: 306.

11-Introduction to Islamic Economics, Ali Mashael, 1st floor, Ras Al Khaimah - United Arab Emirates, 1714-1996 AD: 20

12- Surah Al-Baqarah from verse: 275.

13- Surah An-Nisa from verse 29. 


\section{Volume: 12, Issue: 1, January-March 2022}

14- His saying $\mathrm{Ha}^{\prime}$ and $\mathrm{Ha}^{\prime}$ is a profession of take and give or take and give, and in both of them are the two languages of tide and qasr, and the tide is more eloquent and famous, and its origin is here, so I changed the mother from the kaf. See: Al-Musnad Al-Sahih Al-Mukhtasar Al-Adl Al-Adl Al-Adl to the Messenger of God, may God bless him and grant him peace, Muslim bin Al-Hajjaj Abu Al-Hasan Al-Qushayri AlNaysaburi, (T.: 261 AH), Investigator: Muhammad Fouad Abdul-Baqi, House of Revival of Arab Heritage - Beirut: 3/1209.

15- Al-Jami Al-Sahih Al-Mukhtasar, Muhammad bin Ismail Abu Abdullah Al-Bukhari Al-Jaafi, investigation and commentary: Dr. Mustafa Dib Al-Bagha, 3rd Edition, Dar Ibn Katheer, Al-Yamamah - Beirut, 1407-1987, Chapter of What is Mentioned in the Sale of Food and Hakrah, Hadith No. 2027: 2/750, Sahih Muslim, Chapter on Exchange and Selling Gold in Paper for Cash, Hadith No. 1586: 3/1209.

16-Sahih al-Bukhari, chapter on selling gold for paper hand in hand, Hadith number 2071: 2/762, Sahih Muslim, chapter on the prohibition of selling gold for paper as a debt, Hadith number 1590: 2/1213

17- Sahih al-Bukhari, chapter on selling paper for gold on credit, hadith number 2070: 2/762, Sahih Muslim, chapter on the prohibition of selling paper for gold as a debt, hadith number 1589: 2/1212.

18- The Great Mosque - Sunan Al-Tirmidhi, Muhammad bin Isa bin Surah bin Musa bin Al-Dahhak, Al-Tirmidhi, Abu Issa (died: 279 AH)

19-, Investigator: Bashar Awad Maarouf, Dar al-Gharb al-Islami - Beirut, 1998 AD: $2 / 534$.

20- Al-Minhaj Explanation of Sahih Muslim Bin Al-Hajjaj, Abu Zakaria Mohi Al-Din Yahya Bin Sharaf Al-Nawawi, (T.: 676 AH), i 2, House of Revival of Arab Heritage Beirut, 1392: 11/10.

21-Provisions of money and currency exchange in Islamic jurisprudence and its contemporary applications, d. Abbas Ahmed Muhammad Al-Baz, 1st floor, Dar AlNafais, 1419 AH - 1999 AD: 36.

22- Previous source: 36.

23-Indian Fatwas, Committee of Scholars headed by Nizam al-Din al-Balkhi, 2nd Edition, Dar al-Fikr, 1310 AH: 2/217.

24-Sahih Muslim, Al-Musaqah Book, Chapter on Exchange and Selling Gold in Paper for Cash, Hadith No. 1588/84:3/1212 


\section{Volume: 12, Issue: 1, January-March 2022}

25- Previous source, Al-Musaqah Book, Chapter on Exchange and Selling Gold in Paper for Cash, Hadith No. 1588/85: 3/1212

26- The previous source, Al-Musaqah Book, the chapter on usury, Hadith No. 1584/78: 3 $/ 1209$

27- Tuhfat al-Fuqaha, Muhammad ibn Ahmad al-Samarqandi (T.: 540 AH), Edition 2, Dar al-Kutub al-Ilmiyya, Beirut - Lebanon, 1414 AH - 1994 AD: 3/35.

28- The consensus, Muhammad bin Ibrahim bin Al-Mundhir Al-Nisaburi (died: 318 AH), investigation: Dr. Fouad Abdel Moneim Ahmed, Dar Al-Da`wah, Alexandria, 1402: 92

29- Sahih Muslim, Al-Musaqah Book, Chapter on usury, Hadith No. 1584/77: 3 / 1208

30- Al-Minhaj Explanation of Sahih Muslim bin Al-Hajjaj, Abu Zakaria Al-Nawawi (T.: $676 \mathrm{AH})$, 2nd Edition, House of Revival of Arab Heritage - Beirut 11/14 1392.

31- It is that the two contracting parties, or one of them, stipulate in the contract an option for a known period, so that the owner of the option has the right to sign or cancel the contract during this period. I, Cairo Library, 1388 A.H. - 1968 A.D.: 4/73.

32- Provisions of money and currency exchange in Islamic jurisprudence and its contemporary applications, d. Abbas Ahmed Mohamed El-Baz: 73

33- The Comprehensive Introduction to Islamic Banking Transactions and Operations, Mahmoud Abdel-Karim Irsheed, I 1, Dar Al-Nafaes, Jordan, 2015: 59.

34- Provisions of Money and Currency Exchange in Islamic Jurisprudence and its Contemporary Applications, Abbas Ahmed Muhammad Al-Baz: 205, Shari'a Standards, Accounting and Auditing Organization for Islamic Financial Institutions, (1435 A.H. - 2014 A.D.), Standard No. (1) Currency Trading: 4

35- Provisions of Money and Currency Exchange in Islamic Jurisprudence and its Contemporary Applications, Abbas Ahmed Muhammad Al-Baz: 207, The Comprehensive Introduction to Islamic Banking Transactions and Operations, Mahmoud Abdel-Karim Irsheed: 59.

36- The previous source, Sharia Standards, Accounting and Auditing Organization for Islamic Financial Institutions: 4, Provisions of Exchange in Islamic Jurisprudence, Adel Muhammad Amin Al-Tayeb, Master's Thesis, (1416-1996AD): 264.

37- The provisions of exchange in Islamic jurisprudence, Adel Muhammad Amin AlTayeb: 264, The Comprehensive Introduction to the Transactions and Operations of Islamic Banks, Mahmoud Abdel-Karim Irsheed: 60.

38- Previous source: 266. 


\section{Volume: 12, Issue: 1, January-March 2022}

39- Provisions of Money and Currency Exchange in Islamic Jurisprudence and its Contemporary Applications, Abbas Ahmed Muhammad Al-Baz: 215, The Comprehensive Introduction to Islamic Banking Transactions and Operations, Mahmoud Abdel-Karim Irsheed: 61.

40- Provisions of money and currency exchange in Islamic jurisprudence and its contemporary applications, Abbas Ahmed Muhammad Al-Baz: 216.

41-Consensus, Abu Bakr Muhammad bin Ibrahim bin Al-Mundhir, (T.: 319 AH), Investigator: Fouad Abdel Moneim Ahmed, Edition 1, Dar Al-Muslim (1425 AH / 2004 AD): 97.

42- Musnad of Imam Ahmad bin Hanbal, Abu Abdullah Ahmad bin Muhammad bin Hanbal (T.: 241 AH) Investigator: Shuaib Al Arnaout - Adel Murshid, and others Supervised by: Dr. Abdullah bin Abdul Mohsen Al-Turki, 1st Edition, Message (1421 AH - 2001 AD) No. $15316:$ 2/32.

43- Sharia standards, Accounting and Auditing Organization for Islamic Financial Institutions, Supplement No. (1): 5.

44- The provisions of money and currency exchange in Islamic jurisprudence and its contemporary applications, Abbas Ahmed Muhammad Al-Baz: 221. 


\section{Volume: 12, Issue: 1, January-March 2022}

\section{REFERENCES}

1. The Holy Quran.

2. Muhammad ibn Ibrahim ibn al-Mundhir al-Nisaburi, the consensus, (died: $318 \mathrm{AH}$ ), investigation: Dr. Fouad Abdel Moneim Ahmed, Dar Al-Da`wah, Alexandria, 1402.

3. Adel Muhammad Amin Al-Tayeb, The Rulings of Exchange in Islamic Jurisprudence, Master Thesis, (1416-1996AD).

4. Dr. Abbas Ahmed Muhammad Al-Baz, Rulings on Exchange of Money and Currency in Islamic Jurisprudence and its Contemporary Applications, Edition 1, Dar AlNafais, 1419 AH - 1999 AD.

5. Abu Al-Nada Sharaf Al-Din Al-Hijjawi, Al-Iqnaa, House of Knowledge, Beirut, Lebanon.

6. Zain al-Din Ibn Najim al-Hanafi, The Clear Sea, Explanation of the Treasure of Minutes and Its Margin, Manhat al-Khaliq, Volume 1, Dar al-Kubra al-Arabiya alKubra,

7. Abu Al-Abbas Ahmed bin Muhammad Bel Al-Sawi Al-Maliki, in the language of the traveler to the closest path to the small explanation, Ahmed Al-Dardeer, (T.: 1241 AH), d. i, d. T, House of Knowledge.

8. Muhammad bin Ahmad al-Samarqandi, Tuhfat al-Fuqaha (T.: 540 AH), i 2, Dar alKutub al-Ilmiyya, Beirut - Lebanon, 1414 AH - 1994 AD.

9. Muhammad bin Ismail Abu Abdullah Al-Bukhari Al-Ja'fi, Al-Jami' Al-Sahih AlMukhtasar, investigation and commentary: Dr. Mustafa Dib Al-Bagha, 3rd floor, Dar Ibn Kathir, Al-Yamama - Beirut, 1407 - 1987,

10. Muhammad bin Issa bin Surah bin Musa bin Al-Dahhak, Al-Tirmidhi, Abu Issa, The Great Mosque - Sunan Al-Tirmidhi, (T.: 279 AH), Investigator: Bashar Awad Maarouf, Dar Al-Gharb Al-Islami - Beirut, 1998 AD.

11. Muhammad bin Ahmed bin Arafa Al-Desouki, Al-Desouki's footnote to the Great Commentary, (T.: $1201 \mathrm{AH}$ ), and in the margin the reports of Alish, (T.: 1299 AH), Edition 1, Dar Al-Kutub Al-Ilmiyya, Lebanon - Beirut, 1417 AH - 1997AD.

12. Muhammad Amin Ibn Abidin, footnote to Rad al-Muhtar Ali al-Durr al-Mukhtar, footnote, Dar al-Fikr, Beirut - Lebanon, 1412 AH - 1992 AD

13. Mansour bin Younis bin Idris Al-Bahooti Al-Hanbali, Minutes of Oli Al-Noha for Sharh Al-Muntaha known as Sharh Muntaha Al-Iradat, (T.: 1051 AH), i 1, Alam AlKutub, 1414 AH - 1993 AD. 


\section{Volume: 12, Issue: 1, January-March 2022}

14. Muslim ibn al-Hajjaj al-Nisaburi, Sahih Muslim (T.: 261 AH), Investigator: Muhammad Fouad Abd al-Baqi, Arab Heritage Revival House - Beirut.

15. Indian Fatwas, Committee of Scholars headed by Nizam al-Din al-Balkhi, 2nd Edition, Dar al-Fikr, 1310 AH.

16. Dr. Muhammad Ali Reda Al Jassim, The Basic Rules of the International Economy, Al-Tadamon Press, Baghdad, 1967 AD.

17. Muhammad bin Makram, Ibn al-Manzur, Lisan al-Arab, (T.: 711 AH), Edition 3, Dar Sader Beirut, 1414 AH.

18. Shams Al-Din Abu Bakr Al-Sarakhsi, Al-Mabsout, investigation: Khalil Mohi Al-Din Al-Mays, Edition 1, Dar Al-Fikr, Beirut - Lebanon:

19. Mahmoud Abdel-Karim Irsheed, The Comprehensive Introduction to the Transactions and Operations of Islamic Banks, Edition 1, Dar Al-Nafaes, Jordan, 2015.

20. Ali Mashael, Introduction to Islamic Economics, Edition 1, Ras Al Khaimah - United Arab Emirates, 1714-1996 AD.

21. Abu Abdullah Ahmad bin Muhammad bin Hanbal, Musnad of Imam Ahmad bin Hanbal, (T.: 241 AH) Investigator: Shuaib Al-Arnaout - Adel Murshid, and others Supervision: Dr. Abdullah bin Abdul Mohsen Al-Turki, i 1, the message (1421 AH 2001 AD) ).

22. Muslim bin Al-Hajjaj Abu Al-Hasan Al-Qushayri Al-Nisaburi, the authentic chain of transmission of justice from justice to the Messenger of God, peace be upon him, (T.: $261 \mathrm{AH}$ ), Investigator: Muhammad Fouad Abdel-Baqi, House of Revival of Arab Heritage - Beirut.

23. Sharia Standards, Accounting and Auditing Organization for Islamic Financial Institutions, (1435 AH - 2014 AD),

24. Abu Muhammad Muwaffaq Qudamah al-Maqdisi, the singer by Ibn Qudamah, (died: 620 AH), b. I, Cairo Library, 1388 A.H. - 1968 A.D.

25. Abu Zakaria Muhyi Al-Din Yahya Bin Sharaf Al-Nawawi, Al-Minhaj Sharh Sahih Muslim Bin Al-Hajjaj, (T.: 676 AH), 2nd Edition, House of Revival of Arab Heritage - Beirut, 1392.

26. Adel Hassan Abdul-Mahdi Al-Hamondi, The Economic Encyclopedia, Edition 1, Ibn Khaldoun House, Beirut - Lebanon, 1980 AD.

27. Abdel Aziz Fahmy Heikal, Encyclopedia of Economic and Statistical Terms, Arab Renaissance House, Beirut - Lebanon. 